\title{
Cultural Elements and Women Subservient Roles among Cocoa Farm Families in Southwest Nigeria: Implications for HIV Prevention Strategies.
}

\author{
Famuyiwa, B. S., Williams, O. A., Lawal, J. O., Oduwole, O. O. And \\ Abdul-karim, I. F. \\ Cocoa Research Institute of Nigeria (CRIN)
}

\begin{abstract}
This paper investigated subservient roles and cultural elements that situate women in cocoa farm families in south-western Nigeria to HIV/AIDS. More importantly, women practice of some HIV/AIDS prevention strategies; abstinence, condom use, status check, safe sex, avoid untreated sharp objects avoid transfusion of untested blood and faithfulness were investigated. Multistage sampling procedure was used to select 120 respondents from which information were solicited using a pre-tested interview schedule. The study revealed a mean age of $41.2 \pm 11$ years and $68.33 \%$ into polygamy, while $30 \%$ and $10 \%$ were $2^{\text {nd }}$ and $3^{\text {rd }}$ wife respectively in their families. It was also revealed that though respondents had high knowledge in the HIV prevention strategies; there were low scores in practice of the strategies. There was negative and significant relationship $(r=-0.220 ; p<0.05)$ between subservient roles performed and their practices of HIV/ AID prevention, while negative and significant relationship also existed between sexual servitude and practice of $H I V$ prevention strategies at $(r=-0.44 ; p<0.05)$.
\end{abstract}

Keywords: cultural elements, women, subservient roles, HIV, cocoa farm families and prevention strategies.

\section{Introduction}

HIV/AIDS is an acronym of human immune-deficiency virus (HIV) and acquired immune deficiency syndrome (AIDS). HIV/AIDS is popularly transmitted via sexual intercourse with an infected person or through transfusion of infected blood, injection of contaminated needles, from an infected mother to their child during pregnancy or through breast feeding. Since HIV/AIDS was discovered in 1981, its impact has been particularly severed on the economy of the developing nations (United Nations Development 2010). Its negative impact on agriculture is monumental. AIDS affect the rural household productive capacity by reducing the quality and quantity of household labour and also deplete its financial resources by payment made for medical treatment. (Kwaramba, 1998). This may further lead to reduced household income, asset depletion, and loss of entitlement and increase the number of dependants.

The HIV/AIDS pandemic is no longer restricted to cities. The disease is now spreading at an alarming rate into rural areas, thereby threatening the lives and livelihoods of millions of the rural farming population, especially those in their most productive age bracket of 15 and 49 years (Hilhorst, Liere, Ode and de Konong, 2006, Factsheet, 2011). In most part of Nigeria, rural infection rates are higher than urban (Federal Ministry of Health, 2009) and about 60\% live in rural areas and make their living from agriculture (Omoyibo, Egharevba and Iyanda 2010). In Nigeria, 6 million people (5.4\% of the population) had HIV/AIDS in 2003 and 5.3 million (4.4\% of the population) in 2005 (HIV/AIDS Policy Fact Sheets, 2005). It is currently estimated that $3.6 \%$ of the population is living with HIV/AIDS. (USAID/Nigeria, 2010) Studies on other nations' prevalence rate showed that Nigeria has a higher incidence rate than many other countries around the globe.

The prevalence among women is estimated to be three times higher than men. Female constitute about $58 \%$ about 1.72 million of person living with HIV/AIDS in Nigeria, each year 55\% of aids death occur among women and girls (Factsheet 2011).

In most Sub-Sahara countries, especially in Nigeria, where agriculture is the mainstay of their economy, women are the majority of the workforce, despite all the socio-cultural factors militating against their accessibility to basic resources needed for sustainable livelihood to perform triple role as producers, reproducers and community service provider, HIV/AIDS hit hard on women than men, yielding corresponding decline in agricultural production at both household and community levels. This affects women directly or indirectly. Directly as HIV/AIDS is currently more intense among women, because they are biologically and socioculturally susceptible to the disease and other STDs than men. Indirectly, women as the care givers become affected whenever any member of the family is entrapped by HIV/AIDS.

The patriarchal system or traditionally imposed norms and culture on women limit their access to resources and participation in decision making in Nigeria. Patriarchy is a system of social stratification and differentiation on the basis of gender provides material advantage to males while simultaneously placing severe 
constraints on the roles of females. This gender role differentiation is tied to myth and religion. Religion relegated women to a marginal position thereby reinforcing and sustaining gender inequality. Millett (1997) argued that religion is used as a way of legitimizing male dominance and patriarchy has God on its side. Holms and Bowker (1994) opined that none of the major religions has been particularly good to women.

Patriarchy gives male control over female's sexuality, for instance a Yoruba man in a traditional polygamous arrangement is highly placed than woman, for he controls procreation ability of his wives a well as labour. Men often show off their "wealth" and have more hands in farm labour by the number of wives and children they have (Omoyibo, 2010) while women are expected to be monogamous. In marriage, the age is often lower for females than males as men are expected to have younger sexual partners (WHO, 2010), encouraged to be promiscuous-including in-marriage, women are expected to remain "pure" kept ignorant about sex- this is viewed as a sign of innocence (IRIN 2003). This in turn makes them totally unprepared for sexual relation and equally unable to negotiate for safe sex (Factsheet, 2011). Lack of power to determine when, where and whether sex takes place put women at risk of the disease. One-third $(33 \%)$ of married women in Nigeria are in polygamous union and they lack power to control key aspect of their lives including sexual negotiation in and out of marriage (Factsheet, 2011); about $80 \%$ of infection among women occur in a "stable relationship" where men become infected elsewhere (WHO, 2010). In rural culture where the value of women is dependent on their ability to reproduce, they are compelled to have unprotected sex, placing themselves and their babies at risk due to the fact that more data is available on women during antenatal tests. Females are twice likely than to be infected during unprotected sex (WHO, 2010)

Most harmful sexual practices have their origin in patriarchal societies that promote the superiority of men over women; gender insensitive and gender biased laws which are usually male dominated women keep subservient to men. Gender inequality creates fear of abandonment and rejection in women, as a result, they are not empowered to negotiate safe sex, and also, they find it difficult to insist that men wear condoms (Ezumah, 2003; Smith, 2004). Manus and Bateye, 2006 observed that traditional practices such as widow inheritance, widow "cleansing" and polygamy are recognised as being directly responsible for the spread of HIV/AIDS. All these have detrimental effect on women's health and productivity. Health affects agricultural systems by affecting the health of the producers Donald (2006).

The study focus on cocoa-farming households in the southwest Nigeria, where cocoa is one the most popular crop. Koppelman and French (2005) stated that household is the level at which all farm decisions are made. However, despite the significant role played by women in agricultural production, processing and marketing, men have continued to dominate farm decision making (Barasa, 2006). Studies have assessed the level of awareness of HIV/AIDS among farmers in Ondo State (Adesoji and Olalekan, 2003) and among fishing population in Kogi and Niger States (Olowosegun, 2008), however despite high prevalence rate of infection among women, no study had so far being conducted among women in cocoa farming households. This paper is important because, it could provide baseline information for implementing women's freedom and empowerment to participate in decision making process, at the family and community levels, to both the control and the eradication of HIV/AIDS. This calls for drastic steps to curb the gender inequity problems in decision making in Nigeria, especially in the rural areas, which is exposing the women, who are the majority of the agricultural labour force, to HIV/AIDS plagues.

The objectives of this study are to:

1. identify cultural elements that situate vulnerability of women in cocoa farm families to HIV/AIDS;

2. identify women subservient roles that militate vulnerability to HIV/AIDS among cocoa farm families;

3. assess women adoption quotient of some HIV/AIDS prevention strategies among cocoa farm families in south west Nigeria.

The null hypothesis underlying this study is that there exist no significance relationship between women subservient roles and practice of HIV/AIDS prevention strategies among women in cocoa farm families in southwest, Nigeria.

\section{Methodology}

The study was carried out in the Southwest Nigeria among cocoa farm families. This area comprise six out of thirty-six states; Lagos, Ogun, Osun, Oyo, Ondo, and Ekiti, in Nigeria. Majority of the farm families cultivate average acre of 2.5, intercropping cocoa with crops such kola, plantain, yam, cocoa yam and cassava. Multi-stage sampling procedure was used in selecting the respondents. Stage one is the selection of three states from six states of the southwest Nigeria: Oyo, Ogun and Osun were selected randomly by hat. Stage two involved a purposive selection of two zones of Agricultural Development Programme (ADP) per state, which gave a total of six ADP zones; Saki and Ibadan/Ibarapa in Oyo State, Iwo and Ife/Ijesha in Osun State and Ilaro and Abeokuta Ogun State. Stage three also consists of random selection of two blocks from the lists of blocks per zones selected. The blocks selected were Saki, Igboho, Ido and Akinyele in Oyo State; Iwo, Ejigbo, Ijebu 
jesha and Atakumosa in Osun State; Oke-Odan, Adoodo, Ilugun, and Opeji in Ogun State. Stage four comprised of two cells selected randomly from the selected blocks. Ipokia, Oke-Odan, Ipaja, Ihumbo,Ado-Odo, Ilaro, Iwoye, Owode, Odeda, Osiele, Kila, Olodo, Alabata, Araromi, Opeji and Stage five involved random selection of five farm families from two cells from each of the blocks selected using snow ball techniques. This gave total respondents of 120 farm families.

The data collected were analysed using descriptive such as; frequency count, percentages, means, standard deviation, and inferential statistical techniques; Regression and One way analysis of variance (ANOVA) using SPSS17.

\subsection{Socio-economic characteristics}

\section{Major Findings}

Table 1 showed that majority $(69.17 \%)$ of the respondents are between $31-50$ years with a mean age of 41.15 years.. This indicates that most the women are in the middle age group, sexually active, married and expected to have good knowledge of HIV/AID infection and the prevention strategies. However, $82 \%$ are in polygamous home which can seriously expose the women to HIV/AID infection because the polygamous marriage practices tend to support an equally traditional promiscuous lifestyle for men. The men have at least 2 to 3 wives and this exposes the women to danger of HIV. Over $90 \%$ of the respondents are Yoruba and the culture of the Yoruba has a lot of myth and legend giving dominance to men over the women. Hence, the women are subservient to men especially with regards to sex This gender role differentiation is tied to myth and religion. $47 \%$ of the respondents are Christians while $41 \%$ are Muslim .only $10 \%$ of the are traditional worshippers. As stated earlier, religion relegated women to a marginal position thereby reinforcing and sustaining gender inequality. Religion is used as a way of legitimizing male dominance and patriarchy has God on its side (Millett 1997). It is believed that none of the major religions has been particularly good to women (Holms and Bowker ,1994).

Figure 1 reveals that education among the women is poor with only $10.8 \%$ having completed primary education. Half $(50 \%)$ of the respondents had no formal education and incomplete primary education. About $30 \%$ of the women completed secondary school and attempted to further to post tertiary, while only 5\% completed tertiary school. The low level of education increases the subservient status of the women thereby making them susceptible to HIV plague. This result shows that majority (91\%) of the respondents received primary school and above.

\section{2: Respondent Subservient Status: Sex, economic, social and cultural elements}

Some of the complexities in preventing AID/HIV stemmed from the cultural myths and the under girded belief in gender inequality, specifically, male superiority and women marginalization. This cultural gravitation to male superiority provided other cultural and traditional beliefs in polygamy, wife inheritance and other types of marriage arrangements. Table 2 showed that $98.33 \%$ of the respondents have polygamous family and $85 \%$ with no rights to family planning. Majority of the women do not have right to when $(63.3 \%)$ where $(69.2 \%)$ and how $(70.8 \%)$ to have sex. The polygamous marriage practices tend to support an equally traditional promiscuous lifestyle for men. Different types of cultural arrangements have made it permissible for men to engage in sexual activity with multiple partners. Ezumah (2003) described how inequality and disparity in gender relations affect contraction of HIV. Gender inequality creates fear of abandonment and rejection in women, and as a result, women are not capable of or empowered to negotiate safe sex because they find it difficult or impossible to insist that men wear condoms (Ezumah, 2003; Smith, 2004). These sexual disparities and inequalities between men and women create a cultural imbalance between the genders, and they also limit the available choices and options women have for safe sex (Ezumah; Smith). Studies have shown that cultural practices such as polygamy, wife inheritance and surrogate wife among the Igbos of Anambra state provide a potentially supportive and conducive environment for the contraction and spread of diseases such as HIV/AIDS (Ezumah, 2003; Manus \& Bateye, 2006). This is especially true among women because their subservient traditional cultural roles which culminate to their marginalization have driven the women to the margins of the society. Thus, Anambra state women have become dependent on men not only financially but also in making some personal decisions (Okeibunnor, 1999). The culture of the Igbos of Anambra state condones male supremacy and subjugation of women to men. Thus, many women are not capable of negotiating or empowered to negotiate safe sex because they are too dependent on men to insist that men wear condoms (Ezumah, 2003; Smith, 2003). The culture and gender norms dis- empower women sexually and make them vulnerable to HIV infection (Nguyen, Klot, Phillips \& Pirkle, 2006).

\section{Domestic element}

Women's roles have always been seen to produce children (86.67\%) and be in the kitchen $(62.5 \%)$ as shown in Table 3. The women are so subservient that most of them cannot asked their partners to assist them in 
the kitchen $(75 \%)$ and in washing $(86.7 \%) . .55 \%$ do not have enough money for upkeeps and $69 \%$ cannot make decision to have a maid. Where such decision is made $78.3 \%$ will pay the maid's salary. Therefore, women have become dependent on men not only financially but also in personal decisions (Okeibunnor, 1999).

Furthermore, $75 \%$ of the women cannot decide on their salary and they are not financially empowered as shown in Table 4. 75\% worked compulsorily in the husband farm without payment. $66.6 \%$ of the women who assist their husband on farm do not have a share in the harvest and $60 \%$ do not have access to the profit while $70 \%$ cannot have loan from the profit of the farm for their own business.

.Furthermore, $71 \%$ are deprived from their father's inheritance (Table 6). In most cases male are preferred than female and they are cannot speak or heard where males or men are seated. The male dominance is embedded in the culture such that the husband cannot stay in a house built by the wife (Table 5). The women are socially, culturally and economically deprived to such an extent that they cannot practice HIV/AID prevention methods.

\subsection{Level of Servitude among women in cocoa farm families}

The study revealed in Table 8 that level of servitude among women in cocoa farm families in the study area was slightly low with majority $(53.33 \%)$ in the low servitude group while about $46.67 \%$ was in high servitude level.

\subsection{Knowledge and practice of HIV Prevention Strategies among women in cocoa farm families}

Table 7 shows that there was a distinct difference between knowledge and practice of HIV/AIDS prevention strategies among women in cocoa farm families. The respondents had high knowledge in Condom use; $87.50 \%$ with a low practice of $46.67 \%$, faithfulness; $80.83 \%$ with a practice of $52.50 \%$, while Abstinence, $79.17 \%$ with $40.83 \%$ practice. Though their knowledge on the seven prevention strategies considered were high except for Status check $33.33 \%$ and Safe sex $49.17 \%$ but they all showed a corresponding low practices.

In a situation where there is no hope for cure of HIV, knowledge of prevention is important to reduce vulnerability to the infection. However, knowledge is not important when the information acquired is not put to use. Badcock-walter (2004) adduced that knowledge does not always equal to practice while Asenso-Okyere and Davis (2009) further stated that proper articulation of innovation is as a result of knowledge created, accumulated, shared, used and valued. It may be adduced that the gap between the knowledge and practiced may be explained by subjective norms; which may include some elements of sexual, economic, domestic, and social deprivation embedded in the culture.

Table 9 showed that a sexual element is significantly and negatively correlated to knowledge $(\mathrm{r}=$ $0.478 ; \mathrm{p}<0.001)$ and practice $(\mathrm{r}=-0.436 ; \mathrm{p}<0.001)$ of HIV prevention strategies among women in cocoa farm families in the study area. This is related to the male dominance which is reflected in the polygamous nature of marriage, inability to have rights as to when, where and how to sex. Furthermore faithfulness to their partner cannot be practiced because of polygamy. Even though they have high knowledge of use of condom it cannot be practice and they cannot demand for safe sex. Other cultural elements are not significant. However, domestic, social and cultural elements are negatively correlated with respect to the practice of HIV prevention. Economic element is however positively correlated to knowledge and practice of HIV prevention. This indicates that women cannot practice effectively the HIV prevention strategies and are more vulnerable to HIV because of the subservient status. Education and training may increase their knowledge of the prevention but they may not be able to put it into practice because of their subservient status. Lewis (2013) opined that Nigeria women are more vulnerable to HIV because of their subservient status. The women can only be protected by law, giving them rights to make decisions with regards to sex even concerning their husbands and furthermore they can be empowered financially to carry out regular status checks

\section{Conclusion}

This study revealed that as subservient roles reduce among the respondents, there would be increase in practice of HIV/AIDS prevention strategies, hence the hypothesis is rejected. There is a high level of illiteracy and polygamy in the study area yet the women in cocoa farm households had high knowledge of HIV prevention strategies but a low score in the practice of the strategies. However, there is positive and significant correlation between knowledge and practice of HIV/AID prevention strategies. The low scores observed in the practice of the prevention practices were due to the servitude status of the women. The study revealed that sexual elements explains $47 \%$ of the knowledge of HIV prevention while the low practice is explained by $43 \%$ of the denial of sexual rights of women due to their subservient status This calls for a drastic steps to curb the gender inequity problems in decision making in Nigeria, especially in the rural areas, which is exposing the women, who are the majority of the agricultural labour force, to HIV/AIDS plagues. 


\section{References}

[1]. Adesoji A.A., and Olalekan A.A (2003) Analysis of HIV/AIDS Information Awareness and Effectiveness Among Artisans in Ogbomoso, Oyo State in. Library Philosophy and Practice (e-journal).

[2]. Asenso-Okyere, K. and Davis K. (2009) Knowledge and Innovation for agricultural development. International Food Policy Research Institute (IFPRI). www.ifpri.org/pubs/bp/bp0011.asp

[3]. Badcock-walters, P. Kelly, M. and Gorgenes, M. (2004) Does knowledge equal change? HIV/AIDS Education and Behaviour change 2004. Pp3

[4]. Barasa, C., (2006) Poultry as a tool in Poverty Eradication and Promotion of Gender.

[5]. Donald, C., 2006. Understanding the Links between Agriculture and Health Food, Agriculture and the Environment. Occupational Health Hazard of Agriculture focus 13, Brief 8 of 16.

[6]. Encarta (2010): Encarta (2009) Dictionary.Microsoft@ Encarta® 2009 [DVD].Redmond WA: Microsoft Corporation, 2008

[7]. Ezumah, N. N, (2003) Gender issues in the prevention and control of STIS and HIV/AIDS. Lesson from Awka and Agulu. Anambra State, Nig ,African Journal of Reproductive Health , 7(2) , 89-99. www.ebscohost.com.ezproxy.apollolibrary.com

[8]. Facts Sheets (2005) The HIV/AIDS epidemic in Nigeria. The Kaiser Family Foundation.www.kff.org

[9]. Factsheet (2011) Women, Girls and HIV in Nigeria, Wednesday, 17 August 2011 http://www.naca.gov.ng/index2.php?option

[10]. Federal Ministry of Health (FMOH), (2004) National AIDS/STDs Control Programme, Technical Report on the 2003 National HIV/Syphilis Sentinel Survey Among Pregnant Women Attending Antenatal Clinics in Nigeria. Abuja: Federal Ministry of Health.

[11]. Hilhorst, T., Liere, M.J., Ode, A.V and de Konong, K. (2006) Impact of AIDS on Rural Livelihoods in Benue State, Nigeria. Journal of Social Aspects of HIV/AIDS, $3^{`}$ (1): 381-393.

[12]. Holms J, Bowker J (1994). Women in Religion. London:Pinter.

[13]. IRIN, (2003). Feature-Traditional Culture Spreading HIV/AIDS. IRIN News 28 March 2003,

[14]. Koppelman, R and J.A, French. (2005). A Framework for Understanding Agroforestry decision Making at the Farm Household Level. http://www.fao.org/docrep/x0267e/x0267e00htm-4k

[15]. Kwaramba, P. (1998). The Socio-Economic Impact of HIV/AIDS on Communal Agricultural Systems in Zimbabwe. Working paper No. 19, Economy Advisory Project, Harare: Friedrich-Ebert-Stiftung.

[16]. Lewis, J. (2013) Women in Nigerian culture.www.womenin Nigerian cultureHow.com.htm retrieved March $6^{\text {th }}, 2013$

[17]. Manus U. C. and Bateye, B. O. (2006) The plight of HIV and AIDS Persons in

[18]. Millett, K. (1997). Sexual Politics. New York: Doubleday. www.h-net.org/ women/bibl-millet.html

[19]. Nguyen, V., Klot, J., Phillips, A \& Pirkle, C. (2006). Stigma and discrimination: Culture, HIV and AIDS. Institute of Development Studies. www.eldis.ids.ac.uk

[20]. Okeibunor, J. C. (1999).Threats of AIDS and condom use in a Nigerian urban community: Implications for fertility regulation in Nigeria. Journal of African Anthropology, 36, 1-19. Retrieved July 15, 2006, from www.uaps.org

[21]. Olowosegun, T., Akangbe, J.A., Olowosegun, O.M., Sule, A.M., Sanni,O.A., and Owena, V. (2008). Prevalence of Transactional Sex in Selected Fishing Communities of Kainji Lake Basin. Journal of Nature and Science 2009; 7 (11).

[22]. Omoyibo,K.U., Egharevba, E.M.and Iyanda, O.E. (2010) The Position and Empowerment of Women in Rural Nigeria: the Gender Implication. Journal of Gender and Behavioural: vol 8.2

[23]. Smith, J.D. (2004) Premarital Sex, Procreation and HIV Risk in Nig. stud. Family Plan., 35(4): 223-225.

[24]. Teacher Website (2013) Seven elements of culture. http://www.ocs.cnyric.org/webpages/phyland/global_10.cfm?subpage=19595

[25]. UNAID (2010) Report on the global AIDS epidemic report on HIV and AID, Geneva,

[26]. UNDP (2010) United Nations, Department of Economic and Social Affairs/PopulationDivision 64: The Impact of AIDS on Agriculture pages 60-67

[27]. Webster (2000) Subservient http://www.merriam-webster.com/dictionary/subservient

[28]. WHO (2010) Tuberculosis and HIV/AIDS www.who.int/hiv/topics/tb/en

\section{Tables and Figures}

Table 1: Respondents socio-economic characteristics

\begin{tabular}{|c|c|c|c|c|c|}
\hline $\mathrm{S} / \mathrm{N}$ & Variables & Frequency & Percentage & Mean & Std \\
\hline & Age & & & & \\
\hline & $20-30$ years & 19 & 15.83 & 41.15 & 10.96 \\
\hline & $31-40$ years & 46 & 38.34 & & \\
\hline & 41 - 50 years & 37 & 30.83 & & \\
\hline & $51-60$ years & 11 & 9.17 & & \\
\hline & Above 61 years & 7 & 5.83 & & \\
\hline & Marital status & & & & \\
\hline & Married & 99 & 82.5 & & \\
\hline & Separated & 5 & 4.17 & & \\
\hline & Divorced & 8 & 6.67 & & \\
\hline & Widowed & 8 & 6.67 & & \\
\hline & Family system & & & & \\
\hline & Monogamy & 38 & 31.67 & & \\
\hline & Polygamy & 82 & 68.33 & & \\
\hline & No of wives & & & & \\
\hline & 1 & 38 & 31.67 & 2.26 & 1.24 \\
\hline & 2 & 32 & 26.67 & & \\
\hline & 3 & 35 & 29.17 & & \\
\hline & 4 & 8 & 6.67 & & \\
\hline & 5 & 5 & 4.17 & & \\
\hline & 6 & 1 & 0.83 & & \\
\hline & 7 & 1 & 0.83 & & \\
\hline & Position of wife & & & & \\
\hline & 1 & 69 & 57.5 & & \\
\hline
\end{tabular}




\begin{tabular}{|l|l|r|r|r|l|}
\hline & 2 & 36 & 30 & & \\
\hline & 3 & 12 & 10 & & \\
\hline & 4 & 1 & 0.83 & & \\
\hline & 6 & 1 & 0.83 & & \\
\hline & 7 & 1 & 0.83 & & \\
\hline & Ethnic group & & & & \\
\hline & Yoruba & 108 & 90.00 & & \\
\hline & Hausa & 6 & 5.00 & & \\
\hline & Ibo & 5 & 1 & 4.17 & \\
\hline & Others & 0.83 & & \\
\hline & Religion & 57 & 47.50 & & \\
\hline & Christianity & 50 & 41.67 & & \\
\hline & Muslim & 13 & 10.83 & & \\
\hline & Traditional adherence & & & & \\
\hline
\end{tabular}

Source: Field survey, 2012

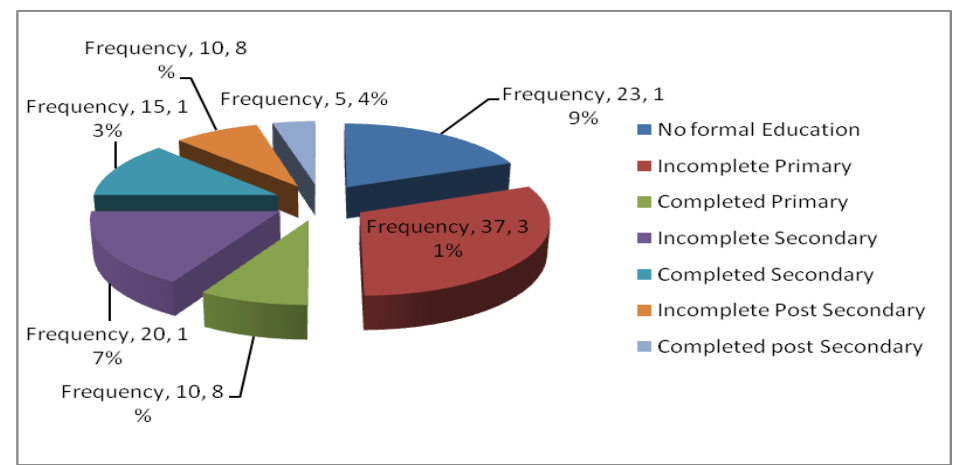

Source: Field survey, 2012

Figure 1: Showing educational levels of respondents

Table 2: Mean scores on the rights of women in cocoa farming to sex

\begin{tabular}{llrrrc}
\hline S/N & Servitude & Frequency & Percentage & Mean & t-test \\
\hline 1 & I am in a polygamous family & 118 & 98.33 & 0.98 & .000 \\
2 & I cannot determine when to have sex & 76 & 63.33 & 0.63 & .000 \\
3 & I cannot determine where to have sex & 83 & 69.17 & 0.69 & .000 \\
4 & I cannot determine how to have sex & 85 & 70.83 & 0.71 & .000 \\
5 & I do not have right to abstain from sex & 70 & 58.33 & 0.58 & .000 \\
6 & I did not have sex education before marriage & 74 & 61.67 & 0.62 & .000 \\
7 & I do not have right to protect myself during sex & 69 & 57.50 & 0.58 & .000 \\
8 & I do not have right to family planning & 102 & 85.00 & 0.85 & .000 \\
\hline
\end{tabular}

Source: Field survey, 2012

Table 3: Mean Score for domestic elements affecting women in cocoa farming from taking HIV/AID prevention Strategies

\begin{tabular}{llrrrc}
\hline S/N & Servitude & Frequency & Percentage & Mean & t-test \\
\hline 1 & It is a must that my place is the kitchen & 75 & 62.50 & 0.63 & .000 \\
2 & It is my sole responsibility to attend to children welfare & 104 & 86.67 & 0.86 & .000 \\
3 & I cannot ask my husband to assist in the kitchen & 90 & 75.00 & 0.75 & .000 \\
4 & I cannot ask my husband to assist in washing & 104 & 86.67 & 0.87 & .000 \\
5 & My husband does not give enough money for up keep & 66 & 55.00 & 0.55 & .000 \\
6 & My husband cannot allow me to have a maid & 83 & 69.17 & 0.69 & .000 \\
7 & If I have a maid I pay her salary & 94 & 78.33 & 0.78 & .000 \\
8 & I cannot cook any food for my husband & 61 & 50.83 & 0.51 & .000 \\
\hline
\end{tabular}

\section{Source: Field survey, 2012}


Table 4:; Mean scores of rights of women in Cocoa farming household to economic benefits

\begin{tabular}{|c|c|c|c|c|c|}
\hline $\mathrm{S} / \mathrm{N}$ & Servitude & Frequency & Percentage & Mean & t-test \\
\hline 1 & I cannot decide fully on my salary & 90 & 75.00 & 0.75 & .000 \\
\hline 2 & I do not have right on the kind of work I do & 44 & 36.67 & 0.37 & .000 \\
\hline 3 & I do not have right to personal farm & 76 & 63.33 & 0.63 & .000 \\
\hline 4 & It is compulsory that I work in my husband farm & 90 & 75.00 & 0.75 & .000 \\
\hline 5 & I am not paid for assistance on my husband farm & 90 & 75.00 & 0.75 & .000 \\
\hline 6 & I do not have share in the harvested crop & 79 & 65.83 & 0.66 & .000 \\
\hline 7 & I do not have access to profit & 72 & 60.00 & 0.60 & .000 \\
\hline 8 & I cannot apply for a loan without my knowledge of my husband & 84 & 70.00 & 0.70 & .000 \\
\hline
\end{tabular}

\section{Source: Field survey, 2012}

Table 5:Mean scores of rights of women in cocoa farming to social needs.

\begin{tabular}{rlrrrr}
\hline S/N & Servitude & Frequency & Percentage & Mean & t-test \\
\hline 1 & I cannot be heard in my house & 73 & 60.83 & 0.61 & .000 \\
2 & I do not have a right to choose a friend & 40 & 33.33 & 0.33 & .000 \\
3 & I do not have a right to choose an opposite gender as friend & 89 & 74.17 & 0.74 & .000 \\
4 & If I have interest in education, my husband will not support & 69 & 57.50 & 0.58 & .000 \\
5 & I cannot build my own house if I have money & 67 & 55.83 & 0.56 & .000 \\
6 & I cannot belong to a society of my own & 70 & 58.33 & 0.58 & .000 \\
7 & I cannot attend meeting at any time & 77 & 64.17 & 0.64 & .000 \\
8 & I cannot speak in the congregation of men & 70 & 58.33 & 0.58 & .000 \\
\hline
\end{tabular}

Source: Field survey, 2012

Table 6: Mean score of rights of women denied by cultural elements

\begin{tabular}{rlllll}
\hline S/N & Servitude & Frequency & Percentage & Mean & t-test \\
\hline 1 & I cannot challenge my husband of infidelity & 75 & 62.50 & 0.63 & .000 \\
2 & I cannot decide on number of children I want & 79 & 65.83 & 0.66 & .000 \\
3 & My husband cannot live in my personal house & 87 & 72.50 & 0.73 & .000 \\
4 & Male child is given preference over female & 67 & 55.83 & 0.56 & .000 \\
5 & I have no say in my father's inheritance & 85 & 70.83 & 0.71 & .000 \\
6 & Soup that husband does not eat I must not cook & 86 & 71.67 & 0.72 & .000 \\
7 & My family still practice wife inheritance & 76 & 63.33 & 0.63 & .000 \\
8 & If I come back again I prefer to be a man & 67 & 55.83 & 0.56 & .000 \\
\hline
\end{tabular}

Source: Field survey, 2012

Table 7: Knowledge and Practice scores on adoption of HIV prevention strategies

\begin{tabular}{|c|c|c|c|}
\hline $\mathrm{S} / \mathrm{N}$ & Variable & Knowledge scores & Practice scores \\
\hline 1 & Abstinence & 95 (79.17) & $49(40.83)$ \\
\hline 2 & Condom use & $105(87.50)$ & $56(46.67)$ \\
\hline 3 & Status check & $40(33.33)$ & 38 (31.67) \\
\hline 4 & Safe sex & $59(49.17)$ & $40(33.33)$ \\
\hline 5 & Blood transfusion & $60(50.00)$ & $54(45.00)$ \\
\hline 6 & Sharp object & 68 (56.67) & $57(47.50)$ \\
\hline 7 & Faithfulness & $97(80.83)$ & $63(52.50)$ \\
\hline
\end{tabular}

Source: Field survey, 2012

Table 8: Level of servitude among the respondents

\begin{tabular}{llll}
\hline Servitude level & Scores & Frequency & Percentage \\
\hline High servitude & $>26.29$ & 56 & 46.67 \\
Low servitude & $<26.29$ & 64 & 53.33 \\
\hline
\end{tabular}

Source: Field survey, 2012

Mean $=26.29$

Standard deviation $=3.56$ 
Cultural Elements and Women Subservient Roles among Cocoa Farm Families in Southwest Nigeria:

Maximum score $=36$

Minimum score $=18$

Table 9: Correlation of factors of servitude with knowledge and practice of HIV prevention

\begin{tabular}{|l|l|l|l|l|l|l|}
\hline & & & $\begin{array}{l}\text { Knowledge of HIV } \\
\text { Prevention }\end{array}$ & Knowledge & $\begin{array}{l}\text { Practice of } \\
\text { HIV } \\
\text { Prevention }\end{array}$ & Practice \\
\hline servitude & Mean & Std Dev. & $\begin{array}{l}\text { Pearson Corr. } \\
\text { Coeff. }\end{array}$ & $\begin{array}{l}\text { T-test. } \\
\text { values }\end{array}$ & $\begin{array}{l}\text { Pearson } \\
\text { Corr.coeff. }\end{array}$ & $\begin{array}{l}\text { T-test } \\
\text { Values }\end{array}$ \\
\hline Sexual & 5.641 & 1.718 & -0.478 & $0.000^{* *}$ & -0.436 & $0.000^{* *}$ \\
\hline Domestic & 5.633 & 1.328 & 0.006 & 0.946 & -0.049 & 0.597 \\
\hline Economic & 5.208 & 1.114 & 0.013 & 0.891 & 0.086 & 0.348 \\
\hline Social & 4.625 & 1.539 & -0.024 & 0.798 & -0.028 & 0.763 \\
\hline Cultural & 5.183 & 1.772 & -0.119 & 0.197 & -0.057 & 0.537 \\
\hline
\end{tabular}

** Sig at $\mathrm{P}=0.001$ 